\title{
Development and Validation of Videogame Addiction Scale for Children (VASC)
}

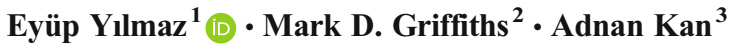

Published online: 15 May 2017

(C) The Author(s) 2017. This article is an open access publication

\begin{abstract}
The aim of the present study was to develop a valid and reliable Videogame Addiction Scale for Children (VASC). The data were derived from 780 children who completed the Videogame Addiction Scale (405 girls and 375 boys; $48.1 \%$ ranging in age from 9 to 12 years). The sample was randomly split into two different sub-samples (sample 1, $n=400$; sample $2, n=380$ ). Sample 1 was used to perform exploratory factor analysis (EFA) to define the factorial structure of VASC. As a result of EFA, a four-factor structure comprising 21 items was obtained and explained $55 \%$ of the total variance (the four factors being "self-control," "reward/reinforcement," "problems," and "involvement"). The internal consistency reliability of VASC has found 0.89. Confirmatory factor analysis (CFA) was performed to confirm the factorial structure obtained by EFA in the remaining half of sample $(n=390)$. The obtained fit indices from the CFA confirmed the structure of the EFA. The 21-item VASC has good psychometric properties that can be used among Turkish schoolchildren populations.
\end{abstract}

Keywords Gaming · Videogames · Videogame addiction · Gaming addiction screening · Youth gaming

With the rapid development of technology and the widespread use of Internet, new forms of leisure activity (online videogames, social networking, etc.) have emerged and are engaged in

Eyüp Yılmaz

eyup.yilmaz@ntu.ac.uk

Mark D. Griffiths

mark.griffiths@ntu.ac.uk

Adnan Kan

adnankan@gazi.edu.tr

1 Psychology Department, Nottingham Trent University, Nottingham, UK

2 International Gaming Research Unit, Psychology Department, Nottingham Trent University, Nottingham, UK

3 Division of Psychology, Gazi University, Ankara, Turkey 
by many individuals including children and adolescents. The videogame industry has become one of the largest industries in terms of both money and audience reached, and for a small minority, the playing of videogames has been reported as being potentially problematic and/or addictive (Gentile 2011; Gentile and Wash 2002).

The latest generation of videogames possesses more stimulating visual and auditory effects, in addition to rapid event frequencies that encourage continuous use ( $\mathrm{Ng}$ et al. 2005). This can lead to individuals spending excessive amounts of time on videogames. Motivations and expectancies can also play a role in excessive gaming (Haagsma et al. 2013). This has led to claims that overusing videogames can lead to a behavioral addiction (Griffiths 2005a). Research has demonstrated that male adolescents are more vulnerable to developing problematic gaming habits and more likely to show signs of pathological gaming than older age groups (Griffiths and Wood 2000; Haagsma et al. 2012).

Many researchers use various terms for videogame addiction including (but not limited to) excessive gaming, problematic gaming use, Internet gaming disorder, compulsive videogame playing, pathological gaming, videogame addiction, digital game addiction, online gaming addiction, and Internet gaming addiction (American Psychiatric Association 2013; Faust and Faust 2015; Gunuc 2015; Huanhuan and Su 2013; Kim and Kim 2010; Kim et al. 2008; Kuss and Griffiths 2012; Lemmens et al. 2011). Irrespective of what it is called, there are similarities in symptoms between addictive behaviors and problematic gaming. Problematic gamers display behavioral tendencies found in more traditional addiction disorders (Van-Holst et al. 2012).

Griffiths (1995) has also claimed that there are two sub-types of addiction referred to as primary and secondary addictions. In primary addictions, the person is addicted to the activity itself and loves engaging the activity. In secondary addiction, the individual engages in the behavior as a way of dealing with other underlying problems. Griffiths (2005a) claims that primary addictions are more resistant to treatment because the person genuinely loves that activity and would not want to willingly give it up whereas secondary addictions are easier to treat because the excessive activity is symptomatic of underlying problems. If the underlying problem is addressed therapeutically, the addictive behavior should diminish. While online gaming addiction was not recognized as a pathological disorder in the fourth edition of the Diagnostic and Statistical Manual of Mental Disorders (American Psychiatric Association [APA] 1994), it features in the in the appendix of the DSM-5 as 'Internet Gaming Disorder.'

The concept of gaming addiction has different core features depending upon the researchers. These include being unable to control the action and continuing the behavior in spite of its negative results (Henderson 2001), an excessive and compulsive use of videogames that results in social and/or emotional problems and that despite these problems, and the gamer being unable to control this excessive use (Lemmens et al. 2009). The APA (2013) define IGD as: "A pattern of excessive and prolonged Internet gaming that results in a cluster of cognitive and behavioral symptoms, including progressive loss of control over gaming, tolerance, and withdrawal symptoms, analogous to the symptoms of substance use disorders" (APA 2013, pp.796).

Videogame playing has a number of factors that make it an attractive and rewarding activity such as social recognition from other players (King and Delfabbro 2009), deriving satisfaction from being part of group and playing for relaxation (Yee 2006), mood regulation, sensation seeking, relieving feelings of boredom and loneliness (Lee and LaRose 2007; Zuckerman 1994), providing escape from daily life problems (Wan and Chiou 2006a, b), and the developing of intimate relationships with others in an imaginary game world that is easier than face-to-face communication (Huanhuan and Su 2013). 
Compared to older video-arcade games and non-continuous forms of gaming, newer computer games and online Internet activities have greater salient effects, stimulating visual and auditory effects and rapid event frequency, which encourage continuous use (Brown and Robertson 1993; Griffiths and Hunt 1998; Ng and Wiemer-Hastings 2005). This is worrisome because such gaming activities and interactive online media are becoming increasingly popular among youth and are proposed to be more addictive than video-arcade games and noncontinuous forms of gambling (Chou and Hsiao 2000; Griffiths et al. 2004; Whang et al. 2003).

The playing of videogames has been discussed in relation to whether the activity is beneficial or harmful for individuals, especially for children and adolescents. Over the past few decades, a growing body of studies has attempted to contribute to the debate. However, it is clear that gaming can have both positive and negative effects depending upon the content and context of game playing. While gamers may spend a lot of time playing videogames, they may also improve their visual attention skills simultaneously (Gentile 2011). There are a considerable number of studies that have found significant associations between excessive online game playing and high levels of depression, anxiety, aggression, trait anxiety, neuroticism, loss of appetite, sleep disturbance, and neglect of physical activity (e.g., Anderson and Murphy 2003; Charlton 2002; Chumbley and Griffiths 2006; Wallenius et al. 2007). Research has also found associations between excessive and compulsive videogame use with poor psychosocial well-being (Lemmens et al. 2011), less satisfaction with daily life (Wang et al. 2008), poor scholastic performance (Gentile et al. 2004; Skoric et al. 2009; Rehbein et al. 2010), and aggression and narcissism (Kim et al. 2008). However, there are many studies that have found positive aspects of videogame playing including high intrinsic motivation (Wan and Chiou 2007), entertainment value (Lim and Lee 2009; Thomas and Martin 2010), educational, social, and/or therapeutic benefits (Griffiths 2002, 2005b; Griffiths 2010a, b), skills enhancement (Gee 2007; Dickey 2011), simulation opportunities to explore environments without risk (Aldrich 2005), and knowledge promotion of computer memory concepts (Papastergiou 2009).

Videogame playing has become one of children's favorite leisure activities. They appear to prefer videogames over television due to the greater control opportunities and active involvement (Greenfield 1984). In the USA, children aged between 2 and 17 years play videogames for an average of $7 \mathrm{~h}$ a week (Gentile and Walsh 2002). In another study, children aged between 9 and 12 years from 12 different countries (Australia, Brazil, Canada, China, Colombia, Finland, India, Kenya, Portugal, South Africa, UK, and USA) spent an average of $8.6 \mathrm{~h}$ engaged in sedentary behavior including videogame playing (LeBlanc et al. 2015). According to the China Internet Network Information Center (CNNIC 2016), children/ adolescents who are aged from from 10 to 19 years constituted $20.1 \%$ of all Internet users in China. Christakis et al. (2004) reported that 5-year-old children spent approximately $4 \mathrm{~h} \mathrm{a}$ week playing videogames. Studies on Turkish children have been shown that children aged 3 to 18 years prefer to play videogames using their own devices (Arnas 2005; Deveci et al. 2007).

There have been many scales developed to assess problematic videogame play. In a systematic review, King et al. (2013) identified 18 different screening instruments including instruments based on gambling or Internet addictions. Some of the most used screens include the Game Addiction Scale (GAS) developed by Lemmens et al. (2009) for adolescents. The scale was developed with data derived from 644 Dutch adolescents aged 12 to 18 years (mean age 14.8 years; $\mathrm{SD}=1.64$ ). The GAS also has been adapted for Brazilian adolescents (Lemos 
et al. 2016), for Turkish adolescents and adults (Baysak et al. 2016), and for French adolescents (Gaetan et al. 2014). A more recent Internet Gaming Disorder Scale Short Form (IGDSSF9) was developed by Pontes and Griffiths (2015). The 7-Item Game Addiction Scale was developed by Khazaal et al. (2016) for French and German speaking adults. Wan and Chiou (2006a, b) developed the Online Game Addiction Scale for Taiwan Adolescents (OAST) for those older than 12 years old. The Problem Videogame Playing (PVP) Scale was developed by Salguero and Moran (2002) for those 13 years old and over. Furthermore, the Videogame Addiction Test (Van Rooij et al. 2012) and Videogame Dependency Scale (Rehbein et al. 2010) were developed for 13-year-old adolescents or over age groups.

Considering the current videogame addiction screens (all of them for those aged over 12 years), we believe that a new videogame addiction scale is needed for young children. There is also a Computer Game Addiction Scale that was developed by Horzum et al. (2008) among Turkish children sample. When the scale items are examined, it can be seen that all of them refer to "playing on a computer". In this case, the children who play videogames but not via their computer (i.e., mobile phone, tablet, Xbox console, PlayStation console etc.) cannot endorse these items. In addition, unlike this study, we aimed to perform confirmatory factor analysis (CFA) to confirm the factor structure obtained via exploratory factor analysis (EFA) and so have an assessment instrument in which validity is tested. We also aimed to compare the factor structure with a larger sample as an another reason to develop a new videogame addiction scale for children. Consequently, the main purpose of this study was to develop a valid and reliable Videogame Addiction Scale for Children (VASC).

\section{Method}

\section{Participants}

The data for scale development were derived from 780 children (405 girls [51.9\%] and 375 boys [48.1\%] ranging in age from 9 to 12 years; mean age $=10.36$ years, $S D=0.49$ ) who participated in the study over a 3-month period (December 2015 to February 2016). Detailed descriptive statistics of the participants are provided in Table 1.

\section{Procedure}

During the process of developing of the draft version of the scale, the related literature and similar scale development studies were reviewed (e.g., DSM-5 2013; Geaten et al. 2014;

Table 1 Detailed descriptive statistics about participants $(N=780)$

\begin{tabular}{|c|c|c|c|c|c|c|c|c|}
\hline \multirow[t]{3}{*}{ Gender } & \multicolumn{6}{|c|}{ Class level } & \multirow{2}{*}{\multicolumn{2}{|c|}{ Total }} \\
\hline & \multicolumn{2}{|c|}{ Fourth grade $(9-10)$} & \multicolumn{2}{|c|}{ Fifth grade $(10-11)$} & \multicolumn{2}{|c|}{ Sixth grade $(11-12)$} & & \\
\hline & $N$ & $\%$ & $n$ & $\%$ & $n$ & $\%$ & $n$ & $\%$ \\
\hline Girl & 140 & 51.7 & 141 & 52.8 & 124 & 51.2 & 405 & 51.9 \\
\hline Boy & 131 & 48.3 & 126 & 47.2 & 118 & 48.8 & 375 & 48.1 \\
\hline Total & 271 & 100 & 267 & 100 & 242 & 100 & 780 & 100 \\
\hline
\end{tabular}


Khazaal et al. 2016; Mak et al. 2014; Lemmens et al. 2009; Lemos et al. 2016; Pontes et al. Griffiths 2015; Pontes et al. 2016; Spekman et al. 2013). The draft scale comprised 31 items. To enable the face and language validity of scale, five Turkish specialists were consulted (an academic from the Division of Assessment and Evaluation in Education, two academic psychologists, a primary school teaching academic, and two classroom teachers). Scale items were also read by nine children (all 9 years old). Items that were not fully understood by the children were replaced until all the items were understood by all nine children.

After ethical approval was granted from the research team's University Ethical Committee, permission to carry out the study was approved by the Turkish Provincial National Education Directorate. Prior to the study, children, the school Principal, and relevant teachers were informed about the purpose of the study. A consent form sent to parents also asked permission for their child to participate in the study. Children assured that their responses would remain confidential and anonymous, and only viewed by the research team (and not shown to their teachers, parents, or friends). A total of 850 children began completing the questions with 780 children completing all of them. Analysis was only carried out on completed questionnaires. Children completed the questionnaire in approximately 25 minutes.

\section{Assessment Materials}

Videogame Addiction Scale for Children The draft form of Videogame Addiction Scale for Children (VASC) comprised 21 items (see Appendix 1 for the Turkish version that was used in the present study; 31 items before the exploratory factor analysis). All items were scored on a five-point scale by the children ("never" = 1, "rarely" = 2, "sometimes" = 3 , "often" = 4, "very often" = 5). Total scores are obtained by summing the children's response scores and total scores range from 21 to 105 . The present authors' recommendation is that a score above 90 indicates a possible addiction to videogames. It is also stressed that this is not a diagnostic tool but only an indicator that a child might have an addiction to videogames. Only an in-depth clinical assessment could provide such a diagnosis.

Socio-Demographics The survey included questions relating to gender, age, socio-economic situation, and whether children had access to technological devices that allowed them to play videogames (personal computer, laptop, tablet, mobile phone, etc.). While the majority of participants $(59.3 \% ; n=463)$ had at least one technological device of their own, one-third of the participants $(32.9 \% ; n=257)$ had to share their technological devices with their siblings, and a small number of participants $(7.8 \% ; n=60)$ did not have their own technological device. One-fifth of participants $(21.1 \% ; n=165)$ had a low socio-economic status, almost a half of participants $(46.2 \% ; n=360)$ had medium socio-economic status, and one-third of participants $(32.7 \% ; n=255)$ had high socio-economic status. Furthermore, boys' VASC scores $(N=341$, $M=57.95, S D=16.49)$ were significantly higher than the girls' VASC scores $(N=379$, $M=43.7, S D=12.11) t=43.7, p<0.01$.

\section{Statistical Analysis}

To test the construct validity of the VASC, an exploratory factor analysis (EFA) was carried out. This was done to test the quality of items, item discrimination index, item difficulty index, item-total correlation analysis, and Cronbach's alpha reliability analysis. All analysis was carried via IBM 
SPSS 21. To be evaluated as a robust scale, the eigen value had to be at least 1 , the factor loading values of the scale items had to be at least .40 , and the load values of items which loaded on more than one factor had to be more than .20 between the load values. To confirm the obtained factor structure of the EFA, confirmatory factor analysis (CFA) was performed using the LISREL 8.80 statistical program. All statistical tests were performed using a significance level of $p<0.05$.

Before testing the factor structure of the Videogame Addiction Scale for Children (VASC), the whole sample was randomly split into the two groups (Sample $1, n=400, M=2.35$, $S D=0.75$; Sample 2, $n=380, M=2.43, S D=0.78$ ). The data of one of these groups was used to determine the dimensional structure of the VASC and the other one was used to confirm the obtained dimensional structure.

\section{Results}

\section{Exploratory Factor Analysis}

As a first step, Kaiser-Meyer-Olkin (KMO) coefficient and Bartlett's test of Sphericity were performed in order to find out whether the VASC is appropriate for principal component analysis. The threshold for the KMO value should be .60 and the data set for $\mathrm{KMO}<.60$ cannot be factored (Field 2000; Pallant and Manual 2001). As a result of analysis, it was found that the dataset was suitable for dimensional structure analysis $\left(\mathrm{KMO}=.91, \chi^{2}=2770.019 ; p<0.01\right)$. EFA was performed via oblimin with Kaiser normalization rotation method to obtain the dimensional structure. Tabachnick and Fiddell (2007) advise looking at the correlations among the factors when trying to decide between orthogonal and oblique rotation (i.e., varimax, direct oblimin, or promax). If the correlations exceed 0.32 , then there is $10 \%$ (or more) overlap in variance among factors and that means enough variance to warrant oblique rotation. Having found correlations over 0.32 between factors (see Table 2), oblimin with Kaiser normalization rotation was performed (Table 3).

Ten items that loaded on more than one factor and had less than .20 factor load difference between factor loads or had less than .40 factor load were removed from scale (i.e., items 1, 4, $6,7,11,12,19,21,24$, and 31) including some items that may be indicative of videogame addiction such as not getting enough sleep and missing meals. A four-factor structure ("selfcontrol," "reward/reinforcement," "problems," and "involvement") comprising 21 items remained that had an eigenvalue greater than 1. Furthermore, Cronbach's alpha coefficient, item-total, and inter-item correlations were computed to examine the internal consistency of the VASC. As a result of reliability analysis, the internal consistency reliability (Cronbach's alpha) of the scale and sub-scales were satisfactory (VASC $=0.89$, self-control $=0.84$, reward/ reinforcement $=0.83$, problems $=0.75$, involvement $=0.73$ ). The results indicated that itemtotal correlations for 21 items ranged from 0.483 to 0.862 . The four factors explained the

Table 2 Correlations among the subscales of the Videogame Addiction Scale for Children

\begin{tabular}{lllll}
\hline & Self-control & Reward/reinforcement & Problems & Involvement \\
\hline Self-control & 1 & .534 & .390 & .625 \\
Reward/reinforcement & & 1 & .120 & .518 \\
Problems & & 1 & .277 \\
Involvement & & & 1 \\
\hline
\end{tabular}

$p<0.01$ 
Table 3 Validity and reliability coefficients of the Videogame Addiction Scale for Children

\begin{tabular}{|c|c|c|c|c|c|}
\hline Factor name & $\begin{array}{l}\text { Item } \\
\text { number }\end{array}$ & Item & $\begin{array}{l}\text { Factor } \\
\text { load }\end{array}$ & $\begin{array}{l}\text { Cronbach's } \\
\text { alpha } \\
\text { (sub-scale) }\end{array}$ & $\begin{array}{l}\text { Cronbach's } \\
\text { alpha } \\
\text { (scale) }\end{array}$ \\
\hline \multirow[t]{7}{*}{ Self-control } & 27 & $\begin{array}{l}\text { I cannot resist playing videogames even if it } \\
\text { negatively affects my life }\end{array}$ & .718 & \multirow[t]{7}{*}{0.84} & \multirow[t]{21}{*}{0.89} \\
\hline & 30 & $\begin{array}{l}\text { Even if I control the amount of time I spend } \\
\text { playing videogames, after a while I continue } \\
\text { to play again uncontrollably }\end{array}$ & .718 & & \\
\hline & 26 & $\begin{array}{l}\text { I feel that whatever I do, I am not able to } \\
\text { control the time I spend playing videogames }\end{array}$ & .656 & & \\
\hline & 20 & $\begin{array}{l}\text { I cannot stop playing videogames even if I } \\
\text { think I have spent so much time playing } \\
\text { them }\end{array}$ & .651 & & \\
\hline & 18 & $\begin{array}{l}\text { I am not interested in anything else while } \\
\text { playing videogames }\end{array}$ & .644 & & \\
\hline & 25 & $\begin{array}{l}\text { Although I want to reduce amount of time I } \\
\text { spend playing videogames, I fail every time }\end{array}$ & .640 & & \\
\hline & 14 & $\begin{array}{l}\text { I forget my problems while playing } \\
\text { videogames }\end{array}$ & .483 & & \\
\hline \multirow[t]{6}{*}{$\begin{array}{l}\text { Reward/ } \\
\quad \text { reinforcement }\end{array}$} & 3 & $\begin{array}{l}\text { In videogames, defeating my enemies/leaping } \\
\text { up a level gives me pleasure }\end{array}$ & .776 & \multirow[t]{6}{*}{0.83} & \\
\hline & 15 & $\begin{array}{l}\text { In videogames, defeating my enemies/leaping } \\
\text { up a level makes me feel stronger than my } \\
\text { enemies. }\end{array}$ & .706 & & \\
\hline & 8 & $\begin{array}{l}\text { I think playing videogames is very enjoyable } \\
\text { activity }\end{array}$ & .700 & & \\
\hline & 17 & $\begin{array}{l}\text { In videogames, defeating my enemies/leaping } \\
\text { up a level increases my self-esteem }\end{array}$ & .693 & & \\
\hline & 13 & I do not feel bored when I play videogames & .660 & & \\
\hline & 29 & I feel happy when I play videogames & .642 & & \\
\hline \multirow[t]{4}{*}{ Problems } & 9 & $\begin{array}{l}\text { Playing videogames prevents me from } \\
\text { fulfilling my responsibilities }\end{array}$ & .862 & \multirow[t]{4}{*}{0.75} & \\
\hline & 5 & $\begin{array}{l}\text { Playing videogames prevents me from eating } \\
\text { regular meals }\end{array}$ & .750 & & \\
\hline & 2 & $\begin{array}{l}\text { The games I play prevent me from spending } \\
\text { time with my family }\end{array}$ & .746 & & \\
\hline & 10 & $\begin{array}{l}\text { I have sleeping problems due to playing } \\
\text { videogames }\end{array}$ & .490 & & \\
\hline \multirow[t]{4}{*}{ Involvement } & 23 & $\begin{array}{l}\text { I always talk about videogames with my } \\
\text { friends }\end{array}$ & .683 & \multirow[t]{4}{*}{0.73} & \\
\hline & 28 & I make friends via online videogames & .673 & & \\
\hline & 22 & $\begin{array}{l}\text { I see my videogames/game characters in my } \\
\text { dreams }\end{array}$ & .624 & & \\
\hline & 16 & $\begin{array}{l}\text { I act like videogame characters in my daily life } \\
\text { activities }\end{array}$ & .513 & & \\
\hline
\end{tabular}

$55.7 \%$ of total variance (self-control $=3.686,17.550$; reward $/$ reinforcement $=3.449,16.425$; problems $=2.416,11.506$; involvement $=2.146,10.218)$.

\section{Confirmatory Factor Analysis}

Confirmatory factor analysis was performed on the 21 items of the VASC using Sample 2 ( $n=380 ; M=2.43, S D=0.78$ ) in order to confirm the four-factor structure (self-control, reward/reinforcement, problems, and involvement) using the Lisrel 8.8 statistical program. The 
standardized path diagram scores of the four-factor structure are shown in Fig. 1. The fourfactor structure resulted in an acceptable model fit and confirmed the four-factor structure obtained via EFA $X^{2}(183, N=380)=535.01, p<.001$. Chi-square $\left(X^{2}\right)$ is a traditional measure that used to assess the fit of the model and to determine the magnitude of the discrepancy between covariance matrices (Hu and Bentler 1999).

The CFA also provided the following results: $X^{2}=2.9$ and $p>.05$, root mean square error of approximation (RMSEA) $=.05$, goodness of fit index $(\mathrm{GFI})=.91$, adjusted goodness of fit index $(\mathrm{AGFI})=.90$, standardized root mean square residual $(\mathrm{SRMR})=.08$, normed fit index $(\mathrm{NFI})=.93$, non-normed fit index $(\mathrm{NNFI})=.96$, and comparative fit index $(\mathrm{CFI})=.96$. Below 0.08 of RMSEA fit indices indicates good harmony (MacCallum et al. 1996); between .90 and .95 of CFI and AGFI fit in indexes are considered as acceptable harmony, and over .95 on these indexes is considered perfect harmony (Hooper et al. 2008; Miles and Shevlin 2007); up to 0.08 of SRMR can be considered acceptable harmony (Byrne 1998); between .90 and .95 of NFI and NNFI is considered acceptable harmony; and over .95 on these fit indexes are considered perfect harmony (Hu and Bentler 1999). All of these results indicate that fourfactor model has an excellent fit and confirms the dimensional structure obtained via EFA.

\section{Discussion}

The main purpose of the present study was to develop a valid and reliable screening instrument to assess videogame addiction among pre-adolescent children (i.e., the Videogame Addiction

Fig. 1 Standardized scores of four-factor structure of the Videogame Addiction Scale for Children

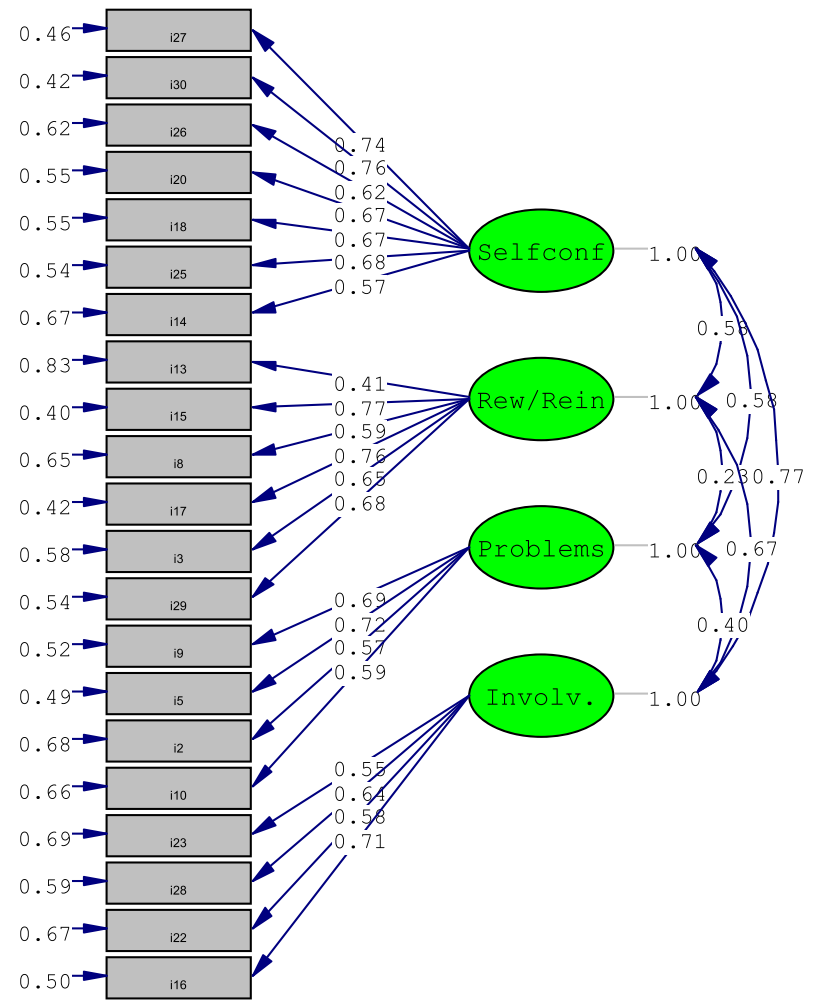


Scale for Children [VASC]). Based on review of the literature, 31 items which have been associated with problematic videogame play were developed. To assess the psychometric characteristics of the VASC, data from the whole sample was randomly split into the two groups (sample $1=400$ participants; sample $2=380$ participants). While Sample 1 was used to determine the dimensional structure of VASC using EFA, Sample 2 was used to confirm the dimensional structured which is obtained using CFA. As a result of the EFA, a four-factor structure [self-control (7 items), reward/reinforcement (6 items), problems (4 items), and involvement (4 items)] emerged comprising 21 items. Confirmatory factor analysis provided evidence of the validity of four-factor structure.

When similar problematic videogame playing scales are examined, some researchers have items based on core addiction components (i.e., salience, tolerance, mood-modification, withdrawal, relapse, conflict, and problems) proposed by Griffiths (2005a) such as the Game Addiction Scale (GAS; Lemmens et al. 2009), the 20-item Internet Gaming Disorder Test (IGD-20; Pontes et al. 2014), Problem Videogame Playing (PVP) Scale (Salguero and Moran 2002), Videogame Addiction Test (Van Rooij et al. 2012), and Young Internet Addiction Scale (YIAS; Young 1996). However, some of scale studies have reported a different dimensional structure such as when validating the Game Addiction Scale Among French and German speaking adults (Khazaal et al. 2016) and the Online Game Addiction Index (OGAI; Zhou and Li 2009; Demetrovics et al. 2012). In the present study, a different dimensional structure (i.e., four-factor structure) was found because the scale items were produced independently of known addiction components. The Cronbach's alpha reliability coefficient was found to be good and Sample 2 confirmed the four-factor structure (i.e., self-control, reward/reinforcement, problems, and involvement).

The result of boys' scores on the VASC was significantly higher than girls' scores. This is similar to the findings of Huanhuan and $\mathrm{Su}$ (2013) who found significantly higher levels of Internet addiction and gaming addiction among boys compared to girls. Brunborg et al. (2013) reported the prevalence of game addiction to be $6.5 \%$ for boys and $2.2 \%$ for girls, with boys playing a mean average of $15 \mathrm{~h}$ a week compared to $5 \mathrm{~h}$ a week for girls. Similar findings have also been found in other studies (e.g., Lemmens et al. 2011; Zorbaz et al. 2015).

The study is not without its limitations. The sample was self-selecting and utilized data collected from Turkish children. Consequently, the findings are not representative of Turkish children and may not be generalizable to other countries. For validation studies, representativeness is not a major issue, and arguably, over-sampling excessive videogame players is more important. However, the present authors were unable to find a way of over-sampling such a group in the way permission was sought to recruit participants, so this is another limitation that needs to be taken into account. All the data were self-report and there suffer from well-known biases including social desirability biases (although the age of sample might be a mitigating factor in this particular instance) and memory recall biases. The initial dataset included responses from 840 children, but data from 60 children (7\% of the initial sample) were discarded due to incomplete responses or recording the same response to every question. It can only be speculated as to why these 60 children did not complete the questionnaire properly (e.g., boredom, simply not wanting to participate even though informed consent had been given by their parents) or whether the omission had any impact on the results found (although the present authors suspect not). Also, there were no data collected that assessed the criterion validity of the VASC (e.g., time spent playing videogames, corroborating evidence from teachers and/or parents, etc.). Such data would be useful to collect in future studies. Furthermore, the scale was designed to be used in epidemiological studies rather than in a 
clinical context, but given the nature of the instrument, in-depth exploration using items in the scale could be used in a clinical context to get a detailed picture of the psychosocial impact of videogame playing in children's lives.

Given that the scale study was developed via Turkish children sample, the VASC needs validating in other languages and cultures to further test the four-factor structure, validity, and reliability of VASC. It also needs further testing among different cohorts of Turkish schoolchildren as the sample in the present study was not necessarily representative. Based on the sample that was tested, it is concluded that the 21-item VASC has good psychometric properties and an established four-factor model confirming the structure with an excellent fit.

\section{Compliance with Ethical Standards}

Conflict of Interest The authors declare that they have no conflict of interest.

Ethical Approval All procedures performed in this study involving human participants were in accordance with the ethical standards of University's Research Ethics Board and with the 1975 Helsinki Declaration.

Informed Consent Informed consent form was delivered to all the parents and children by the investigators included in the study.

\section{Appendix 1 Turkish version of the Videogame Addiction Scale for Children}

\section{ÇOCUKLAR İÇINN VIDEO OYUNLARI BAĞIMLILIĞI ÖLÇEĞİ.}

Așağıdaki sorularda size en uygun olan bölüme (X) ișareti koyunuz

\begin{tabular}{|c|c|c|c|c|c|c|}
\hline $\begin{array}{l}\text { Sira } \\
\text { No }\end{array}$ & Madde & Hiç & Nadiren & Bazen & Genellikle & $\begin{array}{l}\text { Her } \\
\quad \text { Zaman }\end{array}$ \\
\hline 27 & $\begin{array}{l}\text { Günlük hayatımda birçok olumsuzluğa neden olsa bile oyun } \\
\text { oynamaktan kendimi alamam. }\end{array}$ & & & & & \\
\hline 30 & $\begin{array}{l}\text { Oyunlara harcadığım süreyi kontrol altına alsam bile birkaç } \\
\text { gün } \\
\text { sonra tekrar kontrolsüz bir șekilde oynamaya devam ederim. }\end{array}$ & & & & & \\
\hline 26 & $\begin{array}{l}\text { Oyunlara harcadığım süreyi ne yaparsam yapayım kontrol } \\
\text { edemeyeceğimi düşünürüm. }\end{array}$ & & & & & \\
\hline 20 & $\begin{array}{l}\text { Çok uzun süre oyun oynadığımı düşünsem bile oynamayı } \\
\text { bırakamıyorum. }\end{array}$ & & & & & \\
\hline 18 & Oyun oynarken çevremdeki bașka hiçbir șey ilgimi çekmez & & & & & \\
\hline 25 & $\begin{array}{l}\text { Oyunlara harcadığım süreyi azaltmak istememe rağmen her } \\
\text { defasında bașarısız olurum. }\end{array}$ & & & & & \\
\hline 14 & Oyun oynarken hayatımdaki sorunları unuturum. & & & & & \\
\hline 3 & $\begin{array}{l}\text { Oyunda rakiplerimi yenmek, seviye atlamak ya da en } \\
\text { fazla puanı toplamak bana zevk verir. }\end{array}$ & & & & & \\
\hline 15 & $\begin{array}{l}\text { Oyunda rakiplerimi yenmek ya da üst seviyeye çıkmak } \\
\text { onlardan daha güçlü olduğum hissini verir. }\end{array}$ & & & & & \\
\hline 8 & Oyun oynamanın eğlenceli bir etkinlik olduğunu düşünürüm. & & & & & \\
\hline 17 & $\begin{array}{l}\text { Oyunda düșmanlarımı yenmek/seviye atlamak kendime } \\
\text { olan güvenimi artırır. }\end{array}$ & & & & & \\
\hline 13 & Oyun oynarken çok sikılırım. & & & & & \\
\hline 29 & Oyun oynarken kendimi mutlu hissederim. & & & & & \\
\hline 9 & Oyun oynamak sorumluluklarımı yerine getirmemi engeller. & & & & & \\
\hline 5 & Oyun oynamak düzenli bir șekilde yemek yememi engeller. & & & & & \\
\hline 2 & Oynadığım oyunlar ailemle vakit geçirmeme engel olur. & & & & & \\
\hline
\end{tabular}




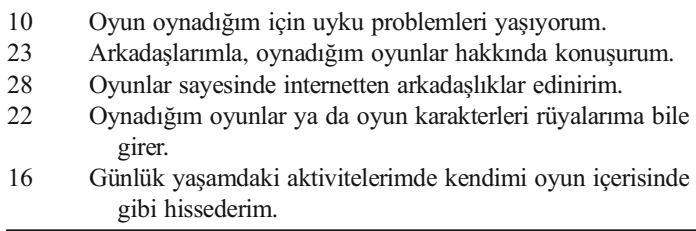

Open Access This article is distributed under the terms of the Creative Commons Attribution 4.0 International License (http://creativecommons.org/licenses/by/4.0/), which permits unrestricted use, distribution, and reproduction in any medium, provided you give appropriate credit to the original author(s) and the source, provide a link to the Creative Commons license, and indicate if changes were made.

\section{References}

Aldrich, C. (2005). Learning by doing: A comprehensive guide to simulations, computer games, and pedagogy in e-learning and other educational experiences. Chichester: John Wiley \& Sons.

American Psychiatric Association. (1994). Diagnostic and statistical manual of mental disorder (4th ed.). Washington, DC: Author.

American Psychiatric Association. (2013). Diagnostic and statistical manual of mental disorder (5th ed.). Washington, DC: Author.

Anderson, C. A., \& Murphy, C. R. (2003). Violent video games and aggressive behavior. Aggressive Behavior, $29,423-429$.

Arnas, Y. A. (2005). 3-18 yaș grubu çocuk ve gençlerin interaktif iletişim araçlarını kullanma alıșkanlıklarının değerlendirilmesi. Turkish Online Journal of Educational Technology, 4(4), 59-66.

Baysak, E., Kaya, F. D., Dalgar, I., \& Candansayar, S. (2016). Online game addiction in a sample from Turkey: Development and validation of the Turkish version of game addiction scale. Klinik Psikofarmakoloji Bulteni, 26(1), 21-31.

Brown, R. I. F., \& Robertson, S. (1993). Home computer and video game addictions in relation to adolescent gambling: Conceptual and developmental aspects. In W. R. Eadington \& J. A. Cornelius (Eds.), Gambling Behavior and Problem Gambling (pp. 451-471). Reno: University of Nevada Press.

Brunborg, G. S., Mentzoni, R. A., Melkevik, O. R., et al. (2013). Gaming addiction, gaming engagement and psychological health complaints among Norwegian adolescents. Media Psychology, 16(1), 115-128.

Byrne, B. M. (1998). Structural equation modeling with Lisrel, Prelis and Simplis: Basic concepts, applications and programming. Mahwah, NJ: Lawrence Erlbaum Associates.

Charlton, J. P. (2002). A factor analytic investigation of computer 'addiction' and engagement. British Journal of Psychology, 93(3), 329-344.

China Internet Network Information Centre (2016). Statistical Report on Internet Development in China. Retrieved January 26, 2017, from: https://cnnic.com.cn/IDR/ReportDownloads/201611/P020161114573409551742.pdf.

Chou, C., \& Hsiao, M. C. (2000). Internet addiction, usage, gratification, and pleasure experience: The Taiwan college students' case. Computers \& Education, 35(1), 65-80.

Christakis, D. A., Ebel, B. E., \& Rivara, F. P. (2004). Television, video and computer game usage in children under 11 years of age. Journal of Pediatrics, 145(5), 652-656.

Chumbley, J., \& Griffiths, M. D. (2006). Affect and the computer game player: The effect of gender, personality, and game reinforcement structure on affective responses to computer game-play. CyberPsychology \& Behavior, 9(3), 308-316.

Demetrovics, Z., Urbán, R., Nagygyörgy, K., Farkas, J., Griffiths, M. D., Pápay, O., et al. (2012). The development of the problematic online gaming questionnaire (POGQ). PLOS ONE, 7(5): e36417.

Deveci, S. E., Yasemin, A. Ç. I. K., Gülbayrak, C., Demir, A. F., Karadağ, M., \& Koçdemir, E. (2007). İlköğretim ögrencilerinin cep telefonu, bilgisayar, televizyon gibi elektromanyetik alan oluşturan cihazları kullanım sıklığı. Firat Tip Dergisi, 12(4), 279-283.

Dickey, M. D. (2011). Murder on Grimm isle: The impact of game narrative design in an educational game based learning environment. British Journal of Educational Technology, 42(3), 456-469.

Faust, K., \& Faust, D. (2015). Refining measures for assessing problematic/addictive digital gaming use in clinical and research settings. Behavioral Sciences, 5, 372-383.

Field, A. (2000). Discovering statistics using SPSS for windows. London: Sage. 
Gaetan, S., Bonnet, A., Brejard, V., \& Cury, F. (2014). French validation of the 7-item game addiction scale for adolescents. Revue Européenne de Psychologie Appliquée/European Review of Applied Psychology, 64(4), $161-168$.

Gee, J. P. (2007). Good video games and good learning: Collected essays on video games, literacy, and learning. New York: Peter Lang.

Gentile, D. A. (2011). The multiple dimensions of video game effects. Child Development Perspectives, 5(2), 75-81.

Gentile, D. A., \& Walsh, D. A. (2002). A normative study of family media habits. Journal of Applied Developmental Psychology, 23(2), 157-178.

Gentile, D. A., Lynch, P. J., Linder, J. R., \& Walsh, D. A. (2004). The effects of violent video game habits on adolescent hostility, aggressive behaviors, and school performance. Journal of Adolescence, 27(1), 5-22.

Greenfield, P. (1984). Media and the mind of the child: From print to television, video games and computers. Cambridge: Harvard University Press.

Griffiths, M. D. (1995). Adolescent gambling. London: Routledge.

Griffiths, M. D. (2002). The educational benefits of videogames. Education and Health, 20(3), 47-51.

Griffiths, M. D. (2005a). A 'components' model of addiction within a biopsychological framework. Journal of Substance Use, 10(4), 191-194.

Griffiths, M. D. (2005b). The therapeutic value of videogames. In J. Goldstein \& J. Raessens (Eds.), Handbook of computer game studies (pp. 161-171). Boston: MIT Press.

Griffiths, M. D. (2010a). The role of context in online gaming excess and addiction: Some case study evidence. International Journal of Mental Health Addiction, 8, 119-125.

Griffiths, M. D. (2010b). Adolescent video game playing: Issues for the classroom. Education Today, 60(4), 3234.

Griffiths, M. D. \& Hunt, N. (1998). Dependence on computer games by adolescents. Psychological Reports, 82, 475-480.

Griffiths, M. D., \& Wood, R. T. (2000). Risk factors in adolescence: The case of gambling, videogame playing, and the internet. Journal of Gambling Studies, 16(2-3), 199-225.

Griffiths, M. D., Davies, M. N., \& Chappell, D. (2004). Online computer gaming: A comparison of adolescent and adult gamers. Journal of Adolescence, 27, 87-96.

Gunuc, S. (2015). Relationships and associations between video game and internet addictions: Is a tolerance a symptom seen in all conditions. Computers in Human Behavior, 49, 517-525.

Haagsma, M. C., Pieterse, M. E., \& Peters, O. (2012). The prevalence of problematic video gamers in the Netherlands. Cyberpsychology, Behavior, and Social Networking, 15(3), 162-168.

Haagsma, M. C., Pieterse, M. E., Peters, O., \& King, D. L. (2013). How gaming may become a problem: A qualitative analysis of the role of gaming related experiences and cognitions in the development of problematic game behaviour. International Journal of Mental Health and Addiction, 11(4), 441-452.

Henderson, E. C. (2001). Understanding addiction. Oxford, Mississippi: University Press of Mississippi.

Hooper, D., Coughlan, J., \& ve Mullen, M. (2008). Structural equation modelling: Guidelines for determining model fit. Electronic Journal of Business Research Methods, 6(1), 53-60.

Horzum, M. B., Ayas, T., Çakır, B., \& Ö. (2008). Computer game addiction scale for children. Turkish Psychological Counselling and Guidance Journal, 3(30), 76-88.

Hu, L. T., \& Bentler, P. M. (1999). Cutoff criteria for fit indexes in covariance structure analysis: Conventional criteria versus new alternatives. Structural Equation Modelling, 6(1), 1-55.

Huanhuan, L., \& Su, W. (2013). The role of cognitive distortion in online game addiction among Chinese adolescents. Children and Young Servises Review, 35, 1468-1475.

Khazaal, Y., Chatton, A., Rothen, S., Achab, S., Thorens, G., Zullino, D., \& Gmel, G. (2016). Psychometric properties of the 7-item game addiction scale among French and German speaking adults. BMC Psychiatry, $16,132$.

Kim, M. G., \& Kim, J. (2010). Cross-validation of reliability, convergent and discriminant validity for the problematic online game use scale. Computers in Human Behavior, 26(3), 389-398.

Kim, E. J., Namkoong, K., Ku, T., \& Kim, S. J. (2008). The relationship between online game addiction and aggression, self-control and narcissistic personality traits. European Psychiatry, 23, 212-218.

King, D. L., \& Delfabbro, P. (2009). Motivational differences in problem video game play. Journal of Cybertherapy and Rehabilitation, 2(2), 139-149.

King, D. L., Haagsma, M. C., Delfabbro, P. H., Gradisar, M. S., \& Griffiths, M. D. (2013). Toward a consensus definition of pathological video-gaming: A systematic review of psychometric assessment tools. Clinical Psychology Review, 33, 331-342.

Kuss, D. J., \& Griffiths, M. D. (2012). Internet gaming addiction: A systematic review of empirical research. International Journal Mental Health Addiction, 10, 278-296. 
LeBlanc, A. G., Katzmarzyk, P. T., Barreira, T. V., Broyles, S. T., Chaput, J. P., Church, T. S., et al. (2015). Correlates of total sedentary time and screen time in 9-11 year-old children around the world: The international study of childhood obesity, lifestyle and the environment. PloS ONE, 10(6), e0129622.

Lee, D., \& LaRose, R. (2007). A socio-cognitive model of video game usage. Journal of Broadcasting \& Electronic Media, 51(4), 632-650.

Lemmens, J. S., Valkenburg, P. M., \& Peter, J. (2009). Development and validation of a game addiction scale for adolescents. Media Psychology, 12(1), 77-95.

Lemmens, J. S., Valkenburg, P. M., \& Peter, J. (2011). Psychosocial causes and consequences of pathological gaming. Computers in Human Behavior, 27(1), 144-152.

Lemos, I. L., Cardoso, A., \& Sougey, E. B. (2016). Validity and reliability assessment of the Brazilian version of the game addiction scale (GAS). Comprehensive Psychiatry, 67, 19-25.

Lim, S., \& Lee, J. E. R. (2009). When playing together feels different: Effects of task types and social contexts on physiological arousal in multiplayer online gaming contexts. Cyberpsychology \& Behavior, 12(1), 59-61.

MacCallum, R. C., Browne, M. W., Sugawara, H., \& M. (1996). Power analysis and determination of sample size for covariance structure modelling. Psychological Methods, 1(2), 130-149.

Mak, K. K., Lai, C. M., Ko, C. H., Chou, C., Kim, D. I., Watanabe, H., \& Ho, R. C. M. (2014). Psychometric properties of the revised chen internet addiction scale (CIAS-R) in Chinese adolescents. Journal of Abnormal Child Psychology, 42(7), 1237-1245.

Miles, J., \& Shevlin, M. (2007). A time and a place for incremental fit indices. Personality and Individual Differences, 42(5), 869-874.

Ng, B. D., \& Wiemer-Hastings, P. (2005). Addiction to the internet and online gaming. CyberPsychology \& Behavior, 8(2), 110-113.

Pallant, J., \& Manual, S. S. (2001). A step by step guide to data analysis using SPSS for windows (versions 10-11). Milton Keynes: Open University Press.

Papastergiou, M. (2009). Digital game-based learning in high school computer science education: Impact on educational effectiveness and student motivation. Computers \& Education, 52(1), 1-12.

Pontes, H. M., \& Griffiths, M. D. (2015). Measuring DSM-5 internet gaming disorder: Development and validation of a short psychometric scale. Computers in Human Behavior, 45, 137-143.

Pontes, H. M., Kiraly, O., Demetrovics, Z., \& Griffiths, M. D. (2014). The conceptualisation and measurement of DSM-5 internet gaming disorder: The development of the IGD-20 test. PloS ONE, 9(10), e110137.

Rehbein, F., Kleimann, M., \& Mößle, T. (2010). Prevalence and risk factors of video game dependency in adolescence: Results of a German nationwide survey. CyberPsychology, Behavior, and Social Networking, 13(3), 269-277.

Salguero, R. A. T., \& Moran, R. M. B. (2002). Measuring problem video game playing in adolescents. Addiction, 97, 1601-1606.

Skoric, M. M., Teo, L. L. C., \& Neo, R. L. (2009). Children and video games: Addiction, engagement, and scholastic achievement. CyberPsychology \& Behavior, 12(5), 567-572.

Spekman, M. L. C., Konijn, E. A, Roelofsma, P. H. M. P. \& Griffiths, M. D. (2013). Gaming addiction, definition, and measurement: A large-scale empirical study. Computers in Human Behavior, 29, 2150-2155.

Tabachnick, B. G., \& ve Fidell, L. S. (2007). Using multivariate statistics (5th ed.). New York: Allyn and Bacon.

Thomas, N. J., \& Martin, F. H. (2010). Video-arcade game, computer game and internet activities of Australian students: Participation habits and prevalence of addiction. Australian Journal of Psychology, 62(2), 59-66.

Van-Holst, R. J., Lemmens, J. S., Valkenburg, P. M., Peter, J., Veltman, D. J., \& Goudriaan, A. E. (2012). Attentional bias and disinhibition toward gaming cues are related to problem gaming in male adolescents. Journal of Adolescent Health, 50(6), 541-546.

Van Rooij, A. J., Schoenmakers, T. M., van de Eijnden, R. J. J. M., Vermulst, A. A., \& van de Mheen, D. (2012). Video game addiction test: Validity and psychometric characteristics. Cyberpsychology, Behavior, \& Social Networking, 15, 507-511.

Wallenius, M., Punamäki, R. L., \& Rimpelä, A. (2007). Digital game playing and direct and indirect aggression in early adolescence: The roles of age, social intelligence, and parent-child communication. Journal of Youth and Adolescence, 36(3), 325-336.

Wan, C. S., \& Chiou, W. (2006a). Psychological motives and online games addiction: A test of flow theory and humanistic needs theory for Taiwanese adolescents. CyberPsychology \& Behavior, 9, 317-324.

Wan, C. S., \& Chiou, W. B. (2006b). Why are adolescents addicted to online gaming? An interview study in Taiwan. CyberPsychology \& Behavior, 9(6), 762-766.

Wan, C. S., \& Chiou, W. B. (2007). The motivations of adolescents who are addicted to online games: A cognitive perspective. Adolescence, 42(165), 179.

Wang, C. K. J., Khoo, A., Liu, W. C., \& Divaharan, S. (2008). Passion and intrinsic motivation in digital gaming. CyberPsychology \& Behavior, 11(1), 39-45. 
Whang, L. S. M., Lee, S., \& Chang, G. (2003). Internet over-users' psychological profiles: A behavior sampling analysis on internet addiction. CyberPsychology \& Behavior, 6(2), 143-150.

Yee, N. (2006). Motivations for play in online games. CyberPsychology \& Behavior, 9(6), 772-775.

Young, K. S. (1996). Internet addiction: The emergence of a new clinical disorder. CyberPsychology \& Behavior, $1,1-12$.

Zhou, Y., \& Li, Z. (2009). Online game addiction among Chinese college students: Measurement and attributions. Studies in Health Technology and Informatics, 144, 149-154.

Zorbaz, S. D., Ulas, O., \& Kizildag, S. (2015). Relation between video game addiction and interfamily relationships on primary school students. Educational Sciences: Theory and Practice, 15(2), 489-497.

Zuckerman, M. (1994). Behavioural expressions and biosocial bases of sensation-seeking. Cambridge: Cambridge University Press. 